\title{
Correction to: Genotoxicity assessment of titanium dioxide nanoparticle accumulation of 90 days in the liver of $g p t$ delta transgenic mice
}

Tetsuya Suzuki ${ }^{1,2}$, Nobuhiko Miura ${ }^{1,3}$, Rieko Hojo ${ }^{1}$, Yukie Yanagiba ${ }^{1}$, Megumi Suda ${ }^{1}$, Tatsuya Hasegawa ${ }^{4}$, Muneyuki Miyagawa ${ }^{1,5}$ and Rui-Sheng Wang ${ }^{1 *}$

\section{Correction to: Genes Environ (2020) 42:7}

https://doi.org/10.1186/s41021-020-0146-3

In the original publication of this article [1], the author made a correction but wasn't carried out. The (Fig. 1b) in sentence "Large clusters containing the TiO NPs were found in the parenchymal hepatocytes (Fig. 1c) and Kupffer cells (Fig. 1b), although the clusters were much more" should be (Fig. 1d).

The original publication has been corrected.

\begin{abstract}
Author details
${ }^{1}$ Division of Industrial Toxicology and Health Effects Research, National Institute of Occupational Safety and Health, 6-21-1 Nagao, Tama-ku, Kawasaki, Kanagawa 214-8585, Japan. ${ }^{2}$ Present address: Graduate School of Biomedical and Health Sciences, Hiroshima University, Hiroshima 734-8553, Japan. ${ }^{3}$ Present Address: Department of Health Science, Yokohama University of Pharmacy, Yokohama 245-0066, Japan. ${ }^{4}$ Division of Human Environmental Science, Mount Fuji Research Institute, Yamanashi Prefectural Government, 5597-1 Kenmarubi, Kamiyoshida, Fujiyoshida, Yamanashi 403-0005, Japan. ${ }^{5}$ Present Address: Department of Sport and Medical Science, Faculty of Medical Technology, Teikyo University, Hachioji, Tokyo 192-0835, Japan.
\end{abstract}

Published online: 03 March 2020

\section{Reference}

1. Suzuki, et al. Genotoxicity assessment of titanium dioxide nanoparticle accumulation of 90 days in the liver of gpt delta transgenic mice. Genes Environ. 2020;42:7. https://doi.org/10.1186/s41021-020-0146-3.

The original article can be found online at https://doi.org/10.1186/s41021 020-0146-3

*Correspondence: wang@h.jniosh.johas.go.jp

'Division of Industrial Toxicology and Health Effects Research, National Institute of Occupational Safety and Health, 6-21-1 Nagao, Tama-ku, Kawasaki, Kanagawa 214-8585, Japan

Full list of author information is available at the end of the article

(c) The Author(s). 2020 Open Access This article is licensed under a Creative Commons Attribution 4.0 International License, which permits use, sharing, adaptation, distribution and reproduction in any medium or format, as long as you give appropriate credit to the original author(s) and the source, provide a link to the Creative Commons licence, and indicate if changes were made. The images or other third party material in this article are included in the article's Creative Commons licence, unless indicated otherwise in a credit line to the material. If material is not included in the article's Creative Commons licence and your intended use is not permitted by statutory regulation or exceeds the permitted use, you will need to obtain permission directly from the copyright holder. To view a copy of this licence, visit http://creativecommons.org/licenses/by/4.0/ The Creative Commons Public Domain Dedication waiver (http://creativecommons.org/publicdomain/zero/1.0/) applies to the data made available in this article, unless otherwise stated in a credit line to the data. 